\title{
BIMBINGAN KONSELING BAGI SISWA DI ERA DISRUPSI
}

\author{
Warsiati \\ Sekolah Tinggi Agama Islam (STAI) Darul Dakwah Wal Irsyad (DDI) kota makassar, Indonesia \\ Email : warsiatiati130200@gmail.com
}

\begin{abstract}
ABSTRAK
Dalam kehidupan manusia ada era dimana terjadinya perubahan besar, perubahan itu dinamakan Era disrupsi. Perubahan yang dirancang oleh manusia yang berupa sumber energi yang serba mesin yang dapat membantu manusia dalam memudahkan atau dapat mengefisienkan segala aktivitasnya yaitu yang dinamakan teknologi. Saat ini teknologi sudah menjadi suatu kebutuhan bagi manusia, karena teknologi menjadikan setiap kehidupan menjadi mudah. Kemanfaatan teknologi dapat dirasakan apabila menggunakannya kearah yang positif dan membangun, salah satunya dalam kegiatan bimbingan konseling berbasis teknologi. Dimana dalam layanan bimbingan dan konseling mampu meningkatkan keterserapan materi yang diberikan kepada siswa atau klien dan dapat mengefektifkan peran konselor sebagai fasilitator guna memandirikan peserta didik di sekolah. Perlunya konselor untuk mengembangkan diri dengan menambah wawasannya agar dapat mengaplikasikan teknologi ke dalam layanan bimbingan dan konseling serta menjadi konselor yang kreatif, adaptif, inovatif, serta fleksibel di era disrupsi ini.
\end{abstract}

Kata kunci : bimbingan, konseling, siswa, disrupsi.

\section{PENDAHULUAN}

Perkembangan teknologi yang semakin pesat berdampak pada semua bidang termasuk bidang pendidikan. Beberapa tahun yang lalu semua hal yang di lakukan seseorang dalam kehidupan dilakukan secara manual berdasarkan berdasarkan potensi seseorang itu sendiri, akan tetapi hal tersebut bertolak belakang dengan keadaan saat ini. salah satu contohnya, beberapa tahun yang lalu Ketika seseorang akan berbalanja dia harus pergi ke toko atau ke supermarket secara langsung berbeda dengan saat ini yang sudah ada system belanja online. Contoh lainnya dalam bidang bimbingan dan konseling beberapa tahun yang lalu pemanfaatan layanan Bimbingan dan Konseling harus dilakukan face to face, akan tetapi semakin berkembangnya teknologi proses kegiatan layanan bimbingan dan konseling dapat dilakukan dengan memanfaatkan teknologi, salah satunya dengan memanfaatkan konseling online (cyber counselling). Dengan kemajuan dan perkembangan teknologi yang semakin pesat tidak dipungkiri terdapat permasalahan perkembangan teknologi bidang bimbingan dan konseling yaitu tidak semua konselor mampu beradaptasi dengan perkembangan kemajuan teknologi. Ketidakmampuan guru bimbingan dan konseling/konselor dalam menggunakan teknologi akan berdampak terhadap proses dan hasil layanan., Sebagai contohnya jika guru bombingan dan konseling/konselor hanya ceramah tanpa menggunakan teknologi sebagai media maka peserta didik akan mengalami kebosanan. Kebosanan peserta didik menyebabkan peserta didik tidak tertarik dan pesan yang akan disampaikan tidak bisa diterima. Oleh karena itu, untuk mengatasi kebosanan peserta didik dalam mengikuti layanan maka penting bagi konselor untuk memanfaatkan teknologi ini. Perkembangan yang pesat dan penggunaan internet untuk menghantarkan informasi dan menyokong komunikasi telah menghasilkan bentuk-bentuk konseling baru salah satunya adalah konseling jarak jauh yang 
dibantu teknologi, yang dapt diperbaharui dengan mudah kaitannya dengan evolusi teknologi dan praktiknya ( Ardi. Z dkk, 2013) ${ }^{1}$

\section{PEMBAHASAN}

\section{Pentingnya Teknologi dalam Bimbingan Konseling di Era Disrupsi}

kegiatan Bimbingan dan Konseling mengacu pada perkembangan dan kemajuan teknolgi yang mutakhir, salahsatunya ialah penggunaan media komunikasi serta informasi elektronik baik secara online maupun offline. Penggunaan media teknologi yang mutakhir akan senantiasa merubah gaya serta penerapan bimbingan dan konseling yang konvensional. Sebagaimana tujuan dari kemajuan teknologi yaitu untuk mengefisienkan atau mempermudah akses informasi, maka penerapannya dalam bimbingan dan konseling juga mengacu pada cara yang sama tanpa mengubah konteks dari bimbingan dan konseling tersebut. Alat atau media dalam akses informasi di era disrupsi ini sangat beragam, seperti telepon selular, komputer, internet dan media lainnya yang langsung atau online ataupun yang tidak langsung atau offline. Maka semua media teknologi informasi tersebut akan mempermudah akses pemberian bantuan terhadap individu jika dimanfaatkan secara tepat guna dan terlatih. Oleh karena itu,professional di bidang bimbingan dan konseling yang selanjutnya disebut dengan konselor, dituntut untuk dapat menggunakan serta terlatih dalam penggunaan dan penerapan konseling melalui media teknologi. Sebagaimana upaya bimbingan dan konseling yaitu menfasilitasi konseli, maka penggunaan teknologi informasi atau media elektronik penunjang proses konseling akan sangat dibutuhkan agar konseli dapat memanfaatkan layanan bimbingan dan konseling secara efisien serta tidak terkesan ketinggalan zaman. Jika layanan bimbingan konseling masih menerapkan car-cara konvensional dalam era teknologi yang semakin maju, maka layanan tersebut akan ditinggalkan oleh konseli yang akan mengakibatkan degradasi moral serta ketidakmampuan konseli dalam memecahkan serta mengoptimalkan tugas perkembangan yang harus dilaluinya secara mandiri. Maka jika hal tersebut terjadi, akan banyak individu yang mengalami kesulitan dalam pemahaman diri dan akan cenderung masuk kedalam zona kebebasan tanpa adanya bimbingan yang bersifat mengembangkan kepribadian kea rah yang baik. ${ }^{2}$

\section{Peranan teknologi dalam bimbingan konseling di Era Disrupsi}

Teknologi informasi dalam layanan bimbingan dan konseling masuk kepada dukungan sistem bimbingan dan konseling sebagai suatu proses pemberian bantuan kepada individu (konseli), dilaksanakan melalui berbagai macam layanan. Layanan tersebut saat ini semakin berkembang, tidak hanya dapat dilakukan dengan tatap muka secara langsung, tapi juga bisa dengan memanfaatkan media atau teknologi informasi yang ada.

Menurut Yoezron (2010), teknologi informasi memiliki beberapa fungsi dan peranan dalam bimbingan konseling yaitu: Pertama Publikasi, teknologi informasi dimanfaatkan sebagai

\footnotetext{
${ }^{1}$ Kusumawati, E. (2020). PELUANG DAN TANTANGAN LAYANAN BIMBINGAN DAN KONSELING DI ERA DISRUPSI. Counsenesia Indonesian Journal Of Guidance and Counseling, 1(02), 64-71. https://doi.org/10.36728/cijgc.v1i02.1184

${ }^{2}$ Sainuddin, I. H., S. (2020, July 27). Dakwah di Era Sosial Media. https://doi.org/10.31219/osf.io/2jxny
} 
sarana pengenalan kepada masyarakat luas dan juga sebagai pemberi informasi mengenai BK. Kedua Pelayanan dan bantuan, dalam fungsi ini bimbingan konseling dilakukan secara tidak langsung dengan bantuan teknologi informasi. Ketiga Pendidikan, dikatakan demikian karena di dalam informasi yang diberikan melalui sarana TI ini mengandung unsur pedidikannya ${ }^{3}$

\section{Kelebihan Penggunaan Teknologi Informasi dalam Bimbingan}

\section{Konseling}

Menurut Zamroni (2012) keuntungan dari guru BK menyelenggarakan BK dengan bantuan teknologi, konselor memiliki kemampuan untuk menggunakan sumber teknologi lain yang dapat dimanfaatkan dalam bimbingan konseling. Hal ini dapat meningkatkan kemampuan diri dan konselor itu sendiri serta membangun prestise dikalangan guru lain disekolah. kelebihan pelayanan bimbingan konseling melalui teknologi informasi, diantaranya:

a) Pelayanan melalui teknologi informasi mudah di akses.

b) Tidak membutuhkan biaya transportasi

c) Mengurangi kesulitan jadwal yang berkaitan dengan program kelompok

d) Pelayanan melalui teknologi informasi bersifat semi anonym

e) Klien lebih mau terbuka berbicara tentang masalahnya karena ia tidak berkomunikasi Secara face to face, sehingga ia dapat lebih siap dan terbuka

f) Pelayanan melalui teknologi informasi dan komunikasi berbasis individu

g) Konselor dapat menyesuaikan kesiapan klien dalam mengambil tindakan yang diperlukan, memotivasi diri, dan meningkatkan keterampilan kliennya

h) Pelayanan melalui teknologi informasi dan komunikasi formatnya harus memfasilitasi konseling yang proaktif

i) Setelah klien membuka komunikasi via teknologi informasi awal, maka konselor berinisiatif untuk memulai suatu kontak berikutnya sehingga ia dapat menciptakan suatu taraf terapis berupa dukungan sosial dan klien bertanggung jawab selama proses penyembuhannya

j) Pelayanan melalui teknologi informasi formatnya menggunakan ijin protokol yang terstruktur. Hal ini memberikan konselor suatu kerangka kerja tertulis yang dapat memastikan pemenuhan topik penting ketika bekerja khusus kepada masing-masing individu pada setiap sesi, sehingga menghasilkan suatu intervesi yang ringkas, terpusat, dan sesuai dengan pribadi klien. ${ }^{4}$

${ }^{3}$ Kusumawati, E. (2020). PELUANG DAN TANTANGAN LAYANAN BIMBINGAN DAN KONSELING DI ERA DISRUPSI. Counsenesia Indonesian Journal Of Guidance and Counseling, 1(02), 71-74 https://doi.org/10.36728/cijgc.v1i02.1184

${ }^{4}$ Aswadi, D., \& Kasmilawati, I. (2020). Penanaman Pendidikan Karakter Anak Melalui Gawai di Era Disrupsi Masa Pandemi Covid-19. STILISTIKA: Jurnal Bahasa, Sastra, dan Pengajarannya, 5(2), 234-245.https://doi.org/10.33654/sti.v5i2.1157 


\section{Strategi bimbingan dan konseling bagi siswa di Era disrupsi}

Strategi bimbingan dan konseling bagi siswa di Era disrupsi sebagai berikut :

a. mendorong dan memfasilitasi siswa dalam menyampaikan ide-ide kreatif dan inovatif,

b. memfasilitasi siswa untuk memodifikasi ide-ide dalam melahirkan inovasi,

c. memberikan umpan balik pada siswa

d. menggunakan informasi dan pengalaman yang ada untuk merumuskan pendekatan/strategi serta model layanan bimbingan dan konseling yang diperlukan. ${ }^{5}$

\section{KESIMPULAN}

Berdasarkan uraian diatas dapat disimpulkan bahwa :

Teknologi informasi merupakan faktor penting dalam proses pelayanan bimbingan dan konseling oleh guru (konselor) sekolah. Adanya pemanfaatan teknologi informasi diharapkan dapat mendorong guru (konselor) untuk lebih kreatif, inovatif, variatif dalam mencari informasi terbaru dalam proses pelayanan. Oleh sebab itu, sebagai guru (konselor) harus bisa memanfaatkan sebaik mungkin teknologi dalam memberikan bimbingan dan koseling terhadap klien/siswa. Agar teknologi bisa dimanfaatkan secara optimal maka tidak akan terlepas dari persepsi atau penilaian guru (konselor) tentang pentingnya teknologi informasi, kemauan, pengetahuan, dan keterampilan guru (konsel or) dalam memanfatkannya untuk proses pelayanan. para akademisi maupun praktisi dibidang bimbingan dan konseling diharapkan untuk selalu meningkatkan kemampuan diri dalam menggunakan teknologi dalam bimbingan dan konseling, guna mengembangkan layanan bimbingan dan konseling yang kreatif, inovatif, adaptif dan dapat memenuhi kebutuhan peserta didik di era disrupsi ini serta selalu melakukan kolaborasi dengan berbagai pihak guna ketercapaiannya dengan tujuan bimbingan dan konseling yang menyeluruh.

${ }^{5}$ Andini, R. D. (2021). STRATEGI PEMIMPIN DALAM DIGITAL LEADERSHIP DI ERA DISRUPSI DIGITAL. AL-IRSYAD, 11(1), 57-71.

http://jurnal.uinsu.ac.id/index.php/alirsyad. 


\section{DAFTAR PUSTAKA}

${ }^{1}$ Kusumawati, E. (2020). PELUANG DAN TANTANGAN LAYANAN BIMBINGAN DAN KONSELING DI ERA DISRUPSI. Counsenesia Indonesian Journal Of Guidance and Counseling, 1(02), 64-71. https://doi.org/10.36728/cijgc.v1i02.1184

${ }^{1}$ Sainuddin, I. H., S. (2020, July 27). Dakwah di Era Sosial Media. https://doi.org/10.31219/osf.io/2jxny.

${ }^{1}$ Kusumawati, E. (2020). PELUANG DAN TANTANGAN LAYANAN BIMBINGAN DAN KONSELING DI ERA DISRUPSI. Counsenesia Indonesian Journal Of Guidance and Counseling, 1(02), 71-74 https://doi.org/10.36728/cijgc.v1i02.1184

${ }^{1}$ Aswadi, D., \& Kasmilawati, I. (2020). Penanaman Pendidikan Karakter Anak Melalui Gawai di Era Disrupsi Masa Pandemi Covid-19. STILISTIKA: Jurnal Bahasa, Sastra, dan Pengajarannya, 5(2), 234-245.https://doi.org/10.33654/sti.v5i2.1157

${ }^{1}$ Andini, R. D. (2021). STRATEGI PEMIMPIN DALAM DIGITAL LEADERSHIP DI ERA DISRUPSI DIGITAL. AL-IRSYAD, 11(1), 57-71.

http://jurnal.uinsu.ac.id/index.php/alirsyad. 